\title{
PUBLIC FINANCIAL INTEREST IN SLOVAK REPUBLIC (CERTAIN REFLECTIONS) ${ }^{1}$
}

\author{
VLADIMÍR BABČ́́K $K^{2}$
}

\begin{abstract}
The contribution deals with issues concerning public financial interest (with emphasis to conditions in the Slovak Republic). These issues are inherently connected with the notion of the private and the public interests. The opposite character of different kinds of interests manifests itself predominately in issues concerning taxation. Author's opinion is that contradictory positions of taxpayers and the state/municipalities in tax matters reflect opposite nature of private and public interests. Abovementioned topic, which is very interesting, is difficult to analyze since various scientific disciplines describe the general notion of interest differently (for example psychology, sociology or pedagogy). The Author describes the notion of interest as the specific focus of an entity: concentrated attention to the certain thing, the certain activity or certain social relations. With that regard, the Author draws the conclusion that political interests are on the top of the hierarchy of interests in the society while economic interests are realized through them.
\end{abstract}

\section{Keywords}

Notion of interests; public interest; private interest; tax law; financial law; taxation and enforcement of interests

\section{JEL Classification: E62, K00, K34}

1 This article presents a partial output of grant project VEGA n.1/0375/15 "Tax evasions and tax frauds and legal possibilities of its prevention (by institutes of tax law, commercial law, and criminal law)".

2 Professor for Tax law, Head of the Department of Financial Law, Tax Law and Economics at the Law Faculty of Pavol Jozef Šafárik, University in Košice since the establishment of the department in 2001 (formerly called the Department of Financial Law and Tax Law). He is generally regarded as the founder of so-called "Kosice school of tax law", which promotes the independent and autonomous status and operation of the tax law within Slovak tax system. He is the author of seven monographs issued in national publishers, co-author of the four monographs published abroad, the author of the twelve university textbooks in the field of financial law and tax law, the author of 47 abroad published scientific studies and contributions to conferences, the author of 54 scientific studies and contributions to domestic scientific conferences, etc. He is a member of Information and Organization Centre for the Research on the Public Finances and Tax Law in the Countries of Central and Eastern Europe. Contact email: vladimir.babcak@upjs.sk. 


\section{Introduction}

Our opinion is that the fiscal interest of the state, as well as the fiscal interest of self-government bodies, has priority among public interests of the state, although this fact is not often empathized. It should be noted (with certain reservation) that described hierarchy of public interests are prevalent mainly in modern states. During the realization of tax law relations and financial relations, the abovementioned fiscal interests are transformed/ incorporated into specific economic policies of the state (containing as their integral parts financial and tax policies).

With that respect, both state and self-government bodies (from the standpoint of the pursuit of public fiscal interest) are primarily concern about financial and tax legal relations. This result from the fact that the achievement of revenue goals that are set in the state budget/municipally budgets (according to specific territorial and temporal conditions) is necessary for the effective realization of the state functions. The executive power branch (mainly state government) in order to gain financial resources prefers the increase in tax rates (or introduction of new tax measures with similar effect) over cuts in budgetary expenditures. As an argument/excuse for that approach the governments often use "standard" excuse that high level of expenditures serves the interests of the general public. It is regrettable that cuts in expenditure are not to the wider extent used to achieve the rational balance between expected revenues and necessary expenditures of the state. It would be the oversimplification to conclude that abovementioned situation only concerns the Slovak Republic.

In dealing with issues concerning public fiscal interest, we need to tackle several questions like:

- what could be regarded as public interest/how could public interest be defined; from which sources does the public interest arise, how is the perception of public interest shaped by government policies and finally, how could be public interest pursued within actual social condition existing within the certain state;

- what is the purpose of public interest and in what cases does it actually serve only as an excuse/argument for people in government pursuing their private/political-power interests (or for interests and economic ambitions of oligarchs and lobbying groups);

- which issues belong exclusively either to the category of private interests or to the category of private interests;

- how to described vague and interdisciplinary notion of public financial interest; 
- which criteria should be used in the assessment of public fiscal interest in Slovak Republic as an EU member state (which membership lasts for 13 years).

It should be noted that aforementioned questions are related to the notion of public interest as described in the contemporary theory of democracy, which teaches that every government decision should closely follow interests of the general public. It should be further noted those terms: "policy/policy decisions" and "public interest" is broad notions that could have the different meaning for different individual economic entities or social groups. Also, varieties of methods are used by different scientific disciplines in approaching questions: whether the certain issue is in public interest or whether certain policy truly promotes the public interest. Such situation is further complicated by the fact that public interest sometimes loses its importance in the realization of state policies in spite of its previous key importance in the policy-making process of these same policies.

In modern democracies, collective decisions are made by referendum and elections. Therefore each policy decision, in theory, should reflect the will of the majority of the population. From this follows that public interest by definition and according to scholarly literature should maximize benefits to a large number of people. Stated conclusion is based on the doctrine of economic individualism, which stresses the primary importance of private interests. In that conceptual framework, the change in perception of the notion of private interests affects the notion of "public interest" (Ivanovič, 2015) as well (which is changing accordingly).

\section{Description of Various Kinds of Interests and of Interaction between Public and Private Interests}

There is a saying: "money rules the world". Majority of people accept stated opinion as a priory true and they do not think about its further implications. Similarly, people react to the question: "who rules/controls the money". Only hardly one could be imagined such state of affairs in which the circulation of money would be totally independent of any other causes. Potential proponents of such possibility could counter this position by the truism that "money brings money (even bigger money) in time". But this is not a valid argument since the increase in any monetary supply does not result from independent "self-circulation" of money. The modus vivendi for growth in monetary mass during time should be therefore described rather by something/someone else than by the money themselves.

There is an evident answer to the question: "who causes the circulation of money". Without the need to look further into that question it is apparent that banks are 
actually entities affecting and causing the circulation of money in the economy. However, the similar simple answer is not satisfactory for the second part of the question: "what causes the money to circulate".

Various possible answers to that question have been proposed, however, in my opinion, the main factors that create the circulation of money in an economy are public and private interests (and therefore interests subsequently shape the very nature of the global economy). With that in mind, we can describe the general notion of interest as the specific focus of an entity: its concentrated attention to the certain thing, a certain activity or certain social relations. My reason for using term entity instead of a person is that the interests do not concern only natural persons but also various other legal subjects (bodies) as well. Naturally, every scientific discipline, which has interests as an object of study, defines them differently.

In my opinion, each interest is a special type of motivational factor. Interest also functions as a global phenomenon that is expressed in a variety of forms according to different social conditions. Each scientific discipline that is studying interests, offers a different classification of interests according to different criteria. Therefore, we may recognize various distinct classifications of interests in psychology, pedagogy or sociology etc.

The most suitable classification of interests divides the interests into two large groups/classes - the class of public interests and the class of private interests. This classification accurately describes the dichotomy between:

a) public and private social spheres,

b) two economic sectors - public sector and private sector ${ }^{3}$

c) public and private finances,

d) public and private law,

e) public and private administration.

The dichotomy of social phenomena listed under para. a) till e) is prima facie apparent. We can ask whether public interests and private interests are in symbiotic/ synergic interaction or whether their distinct features cause them to be antagonistic. With this respect, the founder of the classical economics A. Smith proposed the notion that the harmony in public and private interests could be achieved (Smith, 1997). If he had been alive today, he might have reconsidered his view (if that had that are: public sector, the private sector and third sector (Klimovský, 2014:95-120). However, I do share the view of R.A. Musgrave, of the division of economy into two main sectors: public sector and the private sector. Cooperation between these two sectors is essential for the economy to perform effectively (Musgrave, Musgreová, 1994: 4). 
been the case, his four tax cannons of taxation would have had to wait until their much later discovery).

I am still convinced that to achieve significant development in economic and social relations the symbiotic/synergic interaction between public and private interests must be the highest that is possible. However, in order to achieve that kind of interaction between various interests, the political compromise between the governments, representatives of employers and representative of employees concerning tax and financial matters is of paramount importance.

The above-mentioned classification of interests into the class of public and class of private interests has certain disadvantages since similar classification could be made only in the theoretical and abstract sense. Furthermore, it is highly difficult to classify actual social phenomena exclusively either as private or as public interests (we may mention our reservations towards efforts to do similar classification).

Actual interests manifest themselves in the outside world mainly as political interests. The politics is by definition a tool for enforcement/pursuit of interests. That is the case whether it comes to economic policy, social policy or any other policies; tax policy, the policy of fees, financial policy etc. with no exceptions. The political interests should represent the will of the majority of people who cast their votes in favor of the winner of the election. Therefore the political interests might be in reality very far from actual public interest: the winner/winners need only to successfully persuade the electorate that his/their campaign promises do represent public interests. With that regard, it is not very important whether the winner/ winners is honest with his/their campaign promises or the winner/winners only use his/their promises to sway the election in his/their favor. We are convinced that even if the latter is true, the winner could repeat his success in future elections: which leads to the conclusion that the saying "the voice of the people is the voice of God" is not so true after all.

Also, we must keep in mind that voters are prone to forget (which is often exploited by politicians). In many cases, the notion of "public interest" is used only as a pretext for populist while pursuing their own interests or interests of business groups. On the other hand, if an individual person, social groups, and other political actors do not only follow their private interests, they could be instrumental in the pursuit of public interest.

We may often encounter policy position, which seems to represent public interests, however, in truth, it is only put forward under influence exerted by lobbying organizations, business groups et Cetera. In this case "public interest" in reality stands for private interests of various groups that are working from behind. These private interests (under the cloak of "public interest") root itself into the legal 
regulations and laws (legal acts) reshaping/changing the true essence of public fiscal interest. As a result, private parties secure for themselves economic advantages and achieve monetary profits. Money, which aforementioned groups obtain after this manner, makes their influence in society even stronger. Therefore in my opinion, in the chest of politics beats a heart made of purely economic interests in the situation when politics serves interests of general public and also in situations when it serves interests of business groups. The highest achievement for every kind of interests is to gain political power, which leads to its prevalence in economic power. Therefore the view which sees politics in close proximity to economic interests seems to be accurate. With that regard, the political interests often stand above both the law and justice. This brings us to the central problem: the role of interests in fiscal relations and finally in tax law relations.

\section{Public Fiscal Interest and its Realization (Pursuit) in the Slovak Republic}

To understand the role of various kinds of interests in fiscal relations/tax relations, it is necessary to understand functions, goals, and values, upon which these relations are based. Different subjects view differently issue of compliance in taxation. Tax law is built upon the conflict of interests of entities obliged to pay taxes and of those who are entitled to receive tax revenue.

Fiscal relations and especially tax law relations have always been marked by the contradiction between public interests of state/municipalities and private-economic interests of persons who are obliged to pay taxes (taxpayers). These interests collide especially during the period before the deadline for the submission of the tax return. The interest of the state is to maximize tax revenue. The taxpayers aim for the opposite outcome and regard taxes as the infringement of their right to own property that results in the violation of their personal liberty. The state/municipality impose levy without any direct consideration of the added value, income or property which belongs/is produced by taxpayers. Therefore I think the taxpayers have natural right to reduce (Babčák, 2015: 69) to the smallest possible amount their final tax burden since taxation restricts their fundamental human rights.

Tax administrators and second instance authorities should enforce public interests of the state and municipalities in tax administration. Furthermore, they should protect public interests in tax relations and serve as forbearers and representatives of aforementioned interests. 
These kinds of public interests are monetary by nature. Fiscal interests are expressed in financial regulations and especially tax law regulations. The main body of these legal acts is enacted by parliament and therefore consist mainly of laws (tax laws).

Tax regulations (tax laws) should clearly and persuasively follow public fiscal interest without overtaxing the taxpayers (the over-taxation impose inappropriate tax burden upon taxpayers and does not bring positive effects on national economy). By setting appropriate condition with respect to the taxation, public fiscal interest can be fulfilled. Tax regulations are shaped by conflicts between various kinds of interests (concerning property, religion issues, nationality etc.). Therefore it is the role of tax law to prevent excess in conflicts in tax matters. If the division between various kinds of interests becomes wider the legislation process in tax matter will become more difficult.

We could ask whether tax laws (acts) have some discretion towards limits of the taxation. The natural level of tax burden does exist in every society and it should not be exceeded by the state. Otherwise, taxpayers either would not be able to pay their taxes or doing so they would undermine their source of income and diminish their personal property (Kosikowski, 2014: 10). With that in mind, some Authors (Schultzová, 2015: 20) stress the importance of the so-called sensitive level of the tax burden. That level of tax burden both enhance the effectiveness of tax administration and also motivate taxpayers to do business or to seek new job opportunities.

In the past, the excess in the level of the tax burden was considered to be sinful; however contemporary world does no longer accept this view and therefore taxpayers are prone to sophistically evade paying their taxes. With that respect, Slovakia is trying to tackle the tax evasion (avoidance) by various actions adopted under the OECD's BEPS guidelines (Action Plan on Base Erosion and Profit Shifting ("BEPS")) and EU's action plan ATAP (Commission: COM (2016) 23 final).

The actual role of public interest in tax relations depends on following factors/ effects:

- The fact that taxes are regulated by law and power to tax always emanates from the public authority. Therefore the tax regulations demonstrate their link to public fiscal policy by such characteristics as specific methods of legal regulation; distinct tax principles, specific delimitation of competence between the tax administrators, distinct kind of various tax measures and various kinds of systematic/unsystematic tax measures that may be enacted if it is necessary.

- The tax regulations are often very complicated which is made only worse by an annual increase in a number of paragraphs and pages per legal tax acts, 
this is especially true about laws concerning income tax and value-added tax. This is quite clear from the comparison with the first tax code (Act on Income Taxes) which had only 25 pages of text and 43 paragraphs when it came into effect while 51 pages of texts at the time of its repeal.

- The legislator who intends to lay down strict and precise tax rules often encounters opposition from taxpayers.

- The number of taxpayers obliged to pay different kinds of taxes could be expanded through local inquiry and investigation activity performed by tax administrators.

- There are several unanswered questions on how to effectively secure public/ private interests in tax law relations. Without answering these questions we cannot draw the conclusion about true nature of interests protected by tax legislation. Only some of these questions I shall describe below:

- Do the structure of Slovak tax legislation and the structure of legal acts of the EU - their philosophical framework - serves the public interest or do they serve the private interests?

- Have the private interests (that is to say political-economic interests) rooted into public fiscal interest because of the abovementioned connection between politics and economics and between political and economic interests? All of these factors also affect relations between the EU and its member states: each of the member states pursuits his own "private" interest (metaphorically speaking) and the EU pushes for "public interests" of the whole block. While the EU proclaims to protect fairness (which includes fairness in tax competition) and to promote good governance in tax matters, some EU member states may still be considered tax heavens. I know that the tax professionals are well aware of states I, which I am speaking about, therefore I will not herein list them by their names. We may further ask, what actions have the EU actually made to tackle the tax havens inside its territory and were they effective? In fact, there have been not many such initiatives besides few proposals for new directives and some Commission communications. The fairness in tax matters has become agenda of the EU only during past several years because of a huge increase in cases of international tax avoidance and tax evasion (Commission: COM (2015) 302, Commission: COM (2016) 23).

- When legislator chooses to prefer one of two main principles of taxation either principle of tax fairness or principle of economic efficiency - does he follow either the private interests or public interests? The choice between tax principles is a typical example in which public interest and private interests overlap. In Slovakia, the revaluation of leading tax principles often 
occurs due to change of government, when tax policy and public interest is redefined by political party/parties forming a new government. Because of political struggle, the real economic needs of the state and public fiscal interest often become less important.

- Does granting state aid (Act on State Aid), providing investment incentive (Act on Subsidies to Investment), supporting stimulating measures for research \& development (Act on Stimulus to Research and Development) or conferring any other advantages by the state enhance public interest, or do these fiscal tools serve "in disguise" the private interests of big foreign business companies? If the latter is true, private interests will inevitably root more widely into public fiscal interest. On the other hand, abovementioned fiscal tools may attract foreign capital and strengthen international tax competitiveness of the state. In Slovakia, well-known cases of "state aid" concerned US Steel, various automobile manufacturers as Volkswagen (VW), PSA Peugeot Citroën, KIA Motors and the most recent case concerns Jaguar Land Rover et $\mathrm{al}^{4}$. On the other hand, small and mediumsized enterprises (hereinafter "SMEs") are often overlooked. Their true importance for public fiscal interest is not taken properly into consideration, as though SMEs did not perform any activities that would serve public interests (the assessment of their overall contribution is one-sided and based solely on their private interests).In fact, it is quite the opposite. According to statistical data gathered for the year 2015, SMEs accounted for $99.9 \%{ }^{5}$ of all businesses also SMEs served as employers for $71.8 \%$ of active work-force and created $55.1 \%$ of added value produced in that year (Analysis of SMEs).

Furthermore, there is a question, how to evaluate the shift in taxation from direct to indirect taxes. This shift has occurred as result of Slovak republic joining the EU and it has had a profound impact on the fiscal decentralization in Slovakia. With that respect, we can ask, which interests - public or private - were actually pursued by that significant change in tax policy? My opinion is that there are more reasons behind shift towards indirect taxation than are officially admitted by the government. The official reason in favor of indirect taxes is that the indirect taxation feels psychologically less painful than direct taxes. If that was the only reason, the shift in Slovak tax policy would be the clear manifestation of public interest. However, the situation looks different after we take into account that the shift has helped corporations, especially big businesses to further lower their tax

\footnotetext{
4 The state aid including state tax reliefs was granted to $\mathrm{VW}$ at 17.12 .2008 . With that regard automobile manufacturer, VW had promised until the year 2012 to employ 760 people. That was reflected in tax relief of 2,9 mil. EUR (in the year 2010), 5 mils. EUR (in the year 2011) and tax relief of 6,4 mil. EUR (in the year 2012). Business was actively conducted by 387076 self-employed people. The number of active companies (limited liability companies and joint stock companies) at the end of the year 2015 was 235380 . The annual increase in the number of companies was of 4200 companies (reaching 1.8\%) (www.indexpodnikatelia.sk).
} 
burden, which has been steadily decreasing since the year 1993 (with the exception of one short period of time) ${ }^{6}$. Still, I am not denying that private companies may improve public fiscal interest sometimes even in situations when they pursue private interests. Indeed, the shift of tax policy towards indirect taxation enables the state to achieve revenues without setting high-income tax rates (after all, the creation of revenues is the sole importance of tax system).

I am convinced that all changes in tax regulations should be motivated by public interest and well-being of society as a whole. However, what we should think about the change of tax legislation that negatively affects the legal certainty of taxpayers? Ultimately, that kind of changes goes contrary to the very essence of public fiscal interest and weakens the private interests of businesses sector.

Tax law should guarantee for its addressees' certainty and the legality when it comes to the imposition of tax obligations as well as in conferring the rights. Furthermore, tax law should always avoid creating uncertainty that might affect decision-making process of taxpayers. That kind of changes creating uncertainty especially for business environment clearly goes against the public fiscal interest. Even though the modern world is plagued by tax evasions and tax frauds, stated principles of legal certainty and legality remain essential for tax law.

Every state resp. the international body should seek effective measures to tackle tax evasion, but these measures must be in accordance with these tax principles. It may be noticed that according to European tax survey which was conducted by Deloitte in the year 2015 , almost $40 \%$ of responders chose legal certainty as for the key factor in the building of trust towards tax administration (Deloitte, 2016: 5). I suppose that all tax professionals would agree that trust of taxpayers in tax administration promotes public fiscal interest.

The concept of taxes as compulsory payments is based on the theory of the burden - imposed (forced) unilaterally upon an individual by the state. The taxpayers are required to pay taxes event though it goes contrary to their own private economic interests. This creates tension between private interests of the taxpayers on the one hand and public interest of the state/municipalities on the other. With that regard, it may be further mentioned that each tax regulation enacted by public bodies are binding legal act whether it has or has no any moral status (characteristics).

General view of taxpayers is that the tax obligations are unwanted burden forced upon them against their will. That attitude only deepens when the state manages the

6 In the time period between years 1993 till 2000, the tax rate of corporate income tax was 40\%, from the year 2000 it was lowered to $29 \%$, from 1.1 .2002 it was lowered to $25 \%$, from 1.1 .2004 it was lowered one more to $19 \%$; from the year 2013 tax rate was finally rise to $23 \%$. Actual tax rate $22 \%$ has been in force since the year 2014 and proposal for the lowering of the tax rate to $21 \%$ is now seriously considered. 
tax revenues contrary to principles of economy, efficiency, and effectiveness. With that respect we may provide some examples: the overpricing of tenders, the low quality of work performed by persons to whom the contract is awarded in tender, corruption in tendering process, the involvement of brass plate' companies in public financial relations, the high administrative burden, the granting of state aid primary to foreign investors etc. When business environment due to publicity of corruption scandals lost its trust in public authorities the tax discipline/tax morale it negatively affected. These cases cause huge loss resources that belong to the state, but people in power manage budgetary resources as if they were their own private property.

I am convinced that the tax morale/tax discipline would improve if the general public had more confidence in the sound financial management of the state. If it was the case, taxpayers might view taxation more like an unwritten contract between taxpayers and the state than the unwanted burden imposed unilaterally upon them. To make this change in taxpayer's attitudes, the state should stop its support for individuals who willingly does not work and obtain their income only as state benefits and to start using revenues primarily/exclusively for social goods.

In many cases, the politics/political nominees "hide" themselves behind their posts in administration thus avoiding monetary sanctions for the damage they make to public fiscal interest (by their decisions which they had ostensibly adopted to "promote" public interest). There is nobody among scientific community who would believe that any case of damage incurred by budgetary resources has anything in common with the public interest. Damages for lost budgetary resources may be recovered, through the introduction of new tax instruments - similar to tax licenses - targeting persons who are liable for loss in those resources.

Discussed topics besides legal, economic and political issues also concern variety of questions about ethics in taxation, tax moral/tax discipline and psychological aspects of taxation, however, they go beyond the scope of this article.

\section{Conclusions}

The dynamic relationship between public and private spheres (zones of interests) affects the pursuit of private/public interests in actual social circumstances. Various distinctions between private and public interests affect relations between two main areas of law namely relations between private law and public law.

The social importance of the law is indeed undeniable, but the law sometimes does not achieve desired results in actual social interactions. The law has become seriously infected by economic interests of political parties, lobbying organizations, 
business community even by populists seeking to attract voters (Babčák, 2012: 355). This may be considered new characteristics of contemporary law. While the law it is still created through democratic means/processes, its actual application in many instances diverges from legal principles to the law often ceases to serve the interests of the majority of the population. The law often comes under the influence of various s groups and more often under the influence of politicians with close ties to "big business". What are the implications of such situation? In many cases, private and public interests have become so intertwined than to discover their true nature is nearly impossible. Moreover, the law had lost one of its key attribute that is the ability to successfully prevent future social and economic disruptions by the anticipation of social development. We must face the fact that these unfortunate circumstances have befallen also the tax law.

\section{References}

Babčák, V.: Daňové právo na Slovensku (Tax law in Slovakia), Bratislava: EPOS, 2015.

Babčák, V.: Finančné zákonodarstvo v "službách" stabilizácie a rozvoja slovenskej ekonomiky (Financial law in "services" of stabilization and development of Slovak economy), in: Právo, obchod, ekonomika II., zborník vedeckých prác (Law, Commerce and Economy II, scientific proccedigs), Praha: Leges, 2012.

Klimovský, D.: Základy verejnej správy, druhé, prepracované a doplnené vydanie (Basics of public administration sec. ed.), Bratislava: Wolters Kluwer, 2014.

Kosikowski, C.: Granice opodatkowania - główne problemy (Boundaries of knowledge - main problems), Studia Juridica Cassoviensia no. 2 (2014).

Musgrave, R.A., Musgreová, P.B.: Veřejné finance $\mathrm{v}$ teorii a praxi (Public finances in theory and practise), Praha: Management press, 1994.

OECD: Action Plan on Base Erosion and Profit Shifting, 2013.

Schultzová, A. et al: Daňovníctvo (daňová teória a politika I) (Taxation (theory of taxation and tax policy I)), Praha: Wolters Kluwer, 2015.

Smith, A.: An Inquiry into the Nature and Causes of the Wealth of Nations, Chicago: University of Chicago Press, 1977.

Analýza stavu malého a stredného podnikania (Analysis of SMEs). www.hsr.rok ovania.sk.

Deloitte: European Tax Survey. Transparency, simplification and collaboration. www2.deloitte.com.

Ivanovič, D.: Teória demokracie a koncept verejného záujmu (Theory of democracy and a concept of public interest), Bratislava: e-Polis.cz, 2015.

EU: Communication from the Commission to the European Parliament and the Council form date 28.01.2016 on Anti-Tax Avoidance Package: Next steps towards delivering effective taxation 
Public Financial Interest in Slovak Republic...

and greater tax transparency in the EU (ATAP, Anti-tax avoidance package) no. COM (2016) 23 final.

EU: Communication from the Commission to the European Parliament and the Council, A Fair and Efficient Corporate Tax System in the European Union: 5 Key Areas for Action. COM (2015) 302 final.

EU: Communication from the Commission to the European Parliament and the Council, AntiTax Avoidance Package: Next steps towards delivering effective taxation and greater tax transparency in the EU. COM (2016) 23 final.

SK: Act no. 286/1992 Coll., on Income Taxes, as amended.

SK: Act no. 231/1999 Coll., on State Aid, as amended.

SK: Act no.561/2007 Coll., on Subsidies to Investment, as amended.

SK: Act no. 185/2009 Z. z., on Stimulus to Research and Development. 